\title{
Industry Effect and Stock Market Reaction to Global Financial Crisis: A Comparative Analysis
}

\author{
Nader Alber ${ }^{1}$
}

\begin{abstract}
This paper aims at analyzing the "industry effect" on stock market reaction to global financial crisis. This has been conducted using a sample of 4 stock markets, and covering the period from 2007 to 2011.

Kruskal-Wallis tests indicated that we could accept hypotheses regarding the effects of "industry effect" on stock market reaction to global financial crisis in Egyptian, Kuwaiti, American and British stock markets for all the research period and for the during-crisis period, where the most negatively affected sectors are "insurance" and "real estate" for the Egyptian and the Kuwaiti markets, while "banking" is the most negatively affected sector for the British and American ones. Also, they referred to the need to reject the hypotheses regarding these effects in all stock markets, for the pre-crisis period.

Tests indicated that we could accept hypotheses regarding the effects of "country effect" on stock market reaction to global financial crisis in banking, insurance and real estate sectors. Results of "country effect" tests are consistent with those of "industry effect" in periods and sectors. Tests of the two hypotheses could be considered as robustness checks for each other.
\end{abstract}

JEL classification number: E15

Keywords: Industry effect, stock market, global financial crisis.

\section{Introduction: Nature of the Problem}

Financial markets have expanded their activities, which are reflected by the growing market values from the beginning of this millennium till 2007, while global financial

\footnotetext{
${ }^{1}$ Ain Shams University, Cairo, Egypt.

e-mail: naderalberfanous@yahoo.com

Article Info: Received : January 26, 2013. Revised : February 14, 2013.

Published online : May 1, 2013
} 
crisis has affected this growth from 2008 till 2011. The following table illustrates this:

Table 1: Development of average changes in market indices from 2008 to 2011

\begin{tabular}{c|cccc}
\hline $\begin{array}{c}\text { At } \\
\text { end of }\end{array}$ & $\begin{array}{c}\text { Egyptian } \\
\text { Exchange }\end{array}$ & $\begin{array}{c}\text { Kuwait Stock } \\
\text { Exchange }\end{array}$ & $\begin{array}{c}\text { New York Stock } \\
\text { Exchange }\end{array}$ & $\begin{array}{c}\text { London Stock } \\
\text { Exchange }\end{array}$ \\
\hline 2008 & -0.591 & -0.275 & -0.352 & -0.363 \\
2009 & 0.508 & -0.238 & 0.231 & 0.307 \\
2010 & 0.101 & 0.016 & 0.114 & 0.062 \\
2011 & -0.458 & -0.148 & 0.054 & -0.027 \\
\hline
\end{tabular}

Source: Market indices of these markets: "EGX 30", "Kuwait Stock Exchange Market Index", "FTSE100" and "The Dow Jones U.S. Index".

These average changes of market indices may not express the effect of global financial crisis precisely, as they don't take in account the "industry effect". So, average changes in sectors' indices could shed lights on this. The following table illustrates this:

Table 2: Development of average changes in sector indices from 2008 to 2011

\begin{tabular}{c|ccc|ccc|ccc|ccc}
\hline \multirow{2}{*}{\begin{tabular}{c} 
A $\begin{array}{c}\text { end } \\
\text { of }\end{array}$ \\
\cline { 2 - 11 }
\end{tabular}} & \multicolumn{3}{|c|}{$\begin{array}{c}\text { Egyptian } \\
\text { Exchange }\end{array}$} & \multicolumn{3}{c|}{$\begin{array}{c}\text { Kuwait Stock } \\
\text { Exchange }\end{array}$} & \multicolumn{3}{c|}{$\begin{array}{c}\text { New York Stock } \\
\text { Exchange }\end{array}$} & \multicolumn{3}{c}{$\begin{array}{c}\text { London Stock } \\
\text { Exchange }\end{array}$} \\
\hline 2008 & -0.55 & -0.63 & -0.70 & -0.20 & -0.27 & -0.32 & -0.31 & -0.27 & -0.61 & -0.56 & -0.46 & -0.51 \\
2009 & 0.81 & 0.55 & 0.62 & -0.28 & -0.14 & -0.32 & -0.15 & 0.18 & 0.53 & 0.22 & 0.35 & 0.09 \\
2010 & 0.60 & 0.01 & 0.18 & 0.42 & 0.04 & -0.12 & 0.06 & 0.17 & 0.16 & -0.02 & -0.03 & 0.00 \\
2011 & -0.54 & -0.55 & -0.65 & -0.01 & -0.19 & -0.13 & -0.09 & 0.04 & 0.01 & -0.30 & -0.01 & 0.00 \\
\hline
\end{tabular}

* BAN, INS and REA denote Banking, Insurance and Real Estate sectors respectively.

Source: Sector indices of "Egyptian Exchange", "Kuwait Stock Exchange", "London Stock Exchange" and "New York Stock Exchange".

From here and forthcoming, "Egyptian stock market" denotes "Egyptian Exchange", "Kuwaiti stock market" denotes "Kuwait Stock Exchange", "British stock market" denotes "London Stock Exchange" and "American stock market" denotes "New York Stock Exchange". Also, "Egyptian market index" denotes "EGX 30", "Kuwaiti market index" denotes "Kuwait Stock Exchange Market Index", "British market index" denotes "FTSE100" and "American market index" denotes "The Dow Jones U.S. Index". It's the same for sector indices.

The Current financial crisis came as a great surprise to most people. What initially was seen as difficulties in the US subprime mortgage market, rapidly escalated and spilled over to financial markets all over the world. The crisis has changed the financial landscape worldwide and its costs are yet to be evaluated (Allen et al, 2009, p.1). Many sectors were involved in investigating this crisis. Some concerned with the food and energy crisis that preceded it, while others addressed the US housing mortgage system as a major origin.

The global financial crisis as it has played out in countries across the globe has been manifest in four overlapping phases. Although each phase has a policy focus, each phase of the crisis affects the others, and, until the crisis has passed, no phase seems to have a clear end point. Nanto (2009) summarized the four phases of the global financial crisis as 
follows: contain the contagion and strengthen financial sectors; coping with macroeconomic effects; regulatory and financial market reform and dealing with political, social, and security effects.

Orlweski (2008) identifies five distinctive stages of the current global financial crisis as follows: the outbreak of the subprime mortgage crisis; the proliferation of credit risk, with the broadening of losses of financial institutions; the eruption of liquidity crisis; the commodity price bubble and the ultimate freeze of credit markets.

This paper addresses a main question about effect of "industry effect" on stock market reaction to global financial crisis. This has been conducted using a sample of 4 stock markets, and covering the period from 2007 to 2011. So, this question could be divided into the following:

1- Is there any significant differences between sectors (Banking, Insurance and Real Estate), regarding their reaction to global financial crisis?

2- Is there any significant differences between stock markets (Egyptian, Kuwaiti, American and British), regarding their reaction to global financial crisis?

The paper is arranged as follows: after this introduction, section 2 reviews research literature. Section 3 explains how to measure research variables and illustrates how to test the hypotheses, regarding the "industry effect", using a comparative analysis among Egyptian Exchange, Kuwait Stock Exchange, New York Stock Exchange and London Stock Exchange, during the period of research. Section 4 is for empirical work, presenting results and discussing how these results answer research questions. Section 5 summarizes the paper and provides remarks about conclusions.

\section{Literature Review}

The recent global financial crisis has been discussed through different perspectives. Some address its characteristics within related theories or concepts; some analyzed its origins and consequences, while others compare its effects among sectors and countries.

Global financial crisis could be discussed within efficient market hypothesis; corporate governance, product quality and corporate performance. Ball (2009) associates the "global financial crisis" with the efficient market hypothesis. Despite the theory's undoubted limitations, the claim that it is responsible for the current worldwide crisis seems wildly exaggerated. Ball discusses whether market efficiency is responsible for an asset bubble, for investment practitioners miscalculating risks, and for regulators worldwide falling asleep at the switch. Other claims are that the collapse of Lehman Bros. and other large financial institutions implies market inefficiency, and that an efficient market would have predicted the crash. He argues that these claims are without merit and discusses the evidence of widespread anomalies and the advent of behavioral finance.

According to Becchettiy et al (2010), corporate governance and product quality are two fundamental factors affecting corporate performance and stock market value. In a framework of asymmetric information investors are imperfectly informed about these two factors and have to formulate their expectations according to these signals. Corporate social responsibility (CSR) ratings provide one of the sources of these signals. They use the event study methodology, for abnormal returns of about 2,700 stocks around the event date. Results show that CSR ratings affect abnormal returns and that CSR ratings provide original information which is not captured by indicators of traditional financial rating. Literature of global financial crisis concerns with illustrating banking panics and 
contagion. Academic research proposes two distinct theories to explain the origins of banking panics. One line of argument maintains that panics are caused by random deposit withdrawals unrelated to changes in the real economy. If depositors believe that other depositors will withdraw then all agents find it rational to redeem their claims and a panic occurs. The second set of theories of banking crises is that they are a natural outgrowth of the business cycle. An economic downturn will reduce the value of bank assets, raising the possibility that banks are unable to meet their commitments. If depositors receive information about an impending downturn in the cycle, they will anticipate financial difficulties in the banking sector and try to withdraw their funds. This attempt will precipitate the crisis. (Allen et al, 2009, p.4- 6)

Motivated by the current financial crisis, several papers seek to explain market freezes. Diamond\& Rajan (2009) relate the seizing up of term credit with the overhang of illiquid securities. When banks have a significant quantity of assets with a limited set of potential buyers, shocks in future liquidity demands may trigger sales at fire sale prices. The prospect of a future fire sale of the bank's assets depresses their current value. Acharya et al (2009) show that freeze in markets for rollover debt depend on how information about the quality of the asset is revealed. When there is a constant probability that "bad news" is revealed each period and, in the absence of bad news, the value of the assets is high. By contrast, when there is a constant probability that "good news" is revealed each period and, in the absence of good news, the value of the assets is low.

Another explanation for market freezes relies on asymmetric information. Heider et al (2009) analyze the functioning of interbank markets when there is asymmetric information. As banks face individual liquidity shocks, there is a role for an interbank market in which banks with surplus liquidity can lend to those with liquidity shortage. Asymmetric information about counterparty risk can elevate the interbank market spreads and in extreme situations lead to a total interbank market break down.

Bolton et al (2008) provide a theory of liquidity provision with asymmetric information. According to their model, there is an adverse selection problem due to the superior information that intermediaries have about the assets they hold. If an intermediary is hit by a liquidity shock the problem it faces is whether to try and ride out the crisis or to sell its assets now at a discount. The danger of doing this is that it runs the risk of having to sell at a greater discount if the crisis lasts longer than expected. In the delayed trading equilibrium intermediaries try to ride out the crisis and only sell if they are forced to, while in the immediate trading equilibrium, intermediaries sell assets immediately to ensure they have enough liquidity. (Allen et al, 2009, p.12, 13)

The prevalence of financial crises has led many to conclude that the financial sector is unusually susceptible to shocks. A shock that initially affects only a particular region or sector or perhaps even a few institutions can become systemic and then infect the larger economy (Allen et al, 2009, p.16). The literature on contagion takes two approaches: examining direct linkages and indirect balance-sheet linkages. In looking for contagious effects via direct linkages, Allen\& Gale (2000) study how the banking system responds to contagion when banks are connected under different network structures. To show this, they take the case of an incomplete network where the failure of a bank may trigger the failure of the entire banking system. They prove that, for the same set of parameters, if banks are connected in a complete structure, then the system is more resilient with regard to contagious effects.

Concerned with the optimal financial network, Leitner (2005) constructs a model where the success of an agent's investment in a project depends on the investments of other 
agents she is linked to. Since endowments are randomly distributed across agents, an agent may not have enough cash to make the necessary investment. In this case, agents may be willing to bail out other agents to prevent the collapse of the whole network. Leitner examines the design of optimal financial networks that minimize the trade-off between risk sharing and the potential for collapse.

Parallel to this literature, other researchers applied network techniques developed in mathematics and theoretical physics to study contagion. For instance, Eisenberg\& Noe (2001) investigate default by firms that are part of a single clearing mechanism. First, the authors show the existence of a clearing payment vector that defines the level of connections between firms. Next, they develop an algorithm that allows them to evaluate the effects that small shocks have on the system. This algorithm produces a natural measure of systemic risk based on how many waves of defaults are required to induce a given firm in the system to fail. Similarly, Minguez- Afonso\& Shin (2007) use lattice-theoretic methods to study liquidity and systemic risk in high-value payment systems, such as for the settlement of accounts receivable and payable among industrial firms, and interbank payment systems. Gai\& Kapadia (2007) develop a model of contagion in financial networks and use similar techniques as the epidemiological literature on spread of disease in networks to assess the fragility of the financial system (Allen et al, 2009, p.16, 19).

The second approach to modeling contagion focuses on indirect balance-sheet linkages. Lagunoff\& Schreft (2001) construct a model where agents are linked in the sense that the return on an agent's portfolio depends on the portfolio allocations of other agents. In their model, agents that are subject to shocks reallocate their portfolios, thus breaking some linkages. Two related types of financial crisis can occur in response. One occurs gradually as losses spread, breaking more links. The other type occurs instantaneously when forward-looking agents preemptively shift to safer portfolios to avoid future losses from contagion.

Several papers document empirically how indirect connections between financial institutions pose problems for systemic risk. Adrian\& Brunnermeier (2010) actually propose a new measure for systemic risk that is conditional on an institution (or the whole financial sector) being under distress. Their concern is confirmed by Boyson et al (2008) who find that the average probability that a hedge fund style index has extreme poor performance increases with the number of other hedge funds with extreme poor performance.

Recent contributions have linked the risk of contagion to financial innovation. Parlour\& Winton (2008) analyze the choice a bank has to lay off credit risk between credit default swaps (CDS) and loan sales. With a CDS, the originating bank retains the loan's control rights but no longer has an incentive to monitor; with loan sales, control rights pass to the buyer of the loan. The authors show that when capital costs are low, loan sales are dominant, while when capital costs are high, CDS and loan sales may co-exist. Shin (2009) studies the impact of securitization on financial stability. Since securitization allows credit expansion through higher leverage of the entire financial system, it may drive down lending standards enhancing fragility. Allen \& Carletti (2006) show how financial innovation in the form of credit risk transfer can create contagion across sectors and lower welfare relative to the autarky solution.

Literature of contagion shows that the structure of liquidity shocks hitting the banking sector determines the mechanism for contagion. When banks face a uniform demand for liquidity, they keep a sufficient amount of the short term asset and do not need to raise 
additional liquidity in the market. In this case, credit risk transfer improves risk sharing across sectors. However, when banks face idiosyncratic liquidity shocks, there is scope to invest in the long risk-free asset that can be traded in the market.

The current crisis made it clear we need a broader view on financial systems to capture externalities between institutions. The usual justification for intervention by central banks and governments to prevent the bankruptcy of systemic financial institutions is that this will prevent contagion. This was the argument used by the Federal Reserve for intervening to ensure Bear Sterns did not go bankrupt in March 2008. The bankruptcy of Lehman Brothers a few months later in September of 2008 illustrated how damaging contagion can be. The process did not work in quite the way envisaged in the academic literature and was not accounted for in the decision of the Federal Reserve and Treasure that Lehman should not be saved. After seeing Lehman Brothers collapse, confidence in the creditworthiness of banks and other financial institutions and firms fell significantly and this is when the financial crisis started to spill over into the real economy and had such a damaging effect (Bernanke, 2008; Allen et al, 2009, p.20, 23).

A thorough overview of the events preceding and during the current financial crisis is provided in many papers, covering various sectors and countries (Berger et al, 2009, p.2). Herring\& Wachter (2003) show that many financial crises are results of bubbles in real estate markets. Mayer et al (2009) provide excellent accounts over the developments of the housing market preceding the crisis, due to the low interest rate policies adopted by the Federal Reserve and other central banks after the collapse of the technology stock bubble. They demonstrate various factors helped fuel a dramatic increase in house prices in the U.S. and several other countries such as the U.K., Ireland and Spain.

Berkmen et al (2009) provide one of the first attempts at explaining the differences in the crisis impact across developing countries and emerging markets. Using cross-country regressions, they find that a small set of variables explain a large share of the variation in growth revisions. Countries with more leveraged domestic financial systems and more rapid credit growth tended to suffer larger downward revisions to their growth outlooks.

The authors estimate regressions with the WEO forecast dataset to examine growth revisions for 126 countries, including low-income as well as emerging market countries, and to explore whether other channels, such as trade linkages, mattered for a broader set of countries. Interestingly, the trade channel appears to matter in this sample. Although the degree of trade openness is not statistically significant, the composition of trade makes a significant difference. In particular, the share of commodities (both food and overall) in total exports is associated with smaller downward growth revisions. The share of manufacturing products in total exports is correlated with worse growth performance both for advanced as well as developing countries. This is consistent with the notion that countries exporting manufacturing goods to advanced countries seem to have been hit hard by the decline in demand from these markets, while countries exporting food appear to have fared better.

Hasan.\& Dridi (2010) examines the performance of Islamic banks (IBs) and conventional banks (CBs) during the recent global crisis by looking at the impact of the crisis on profitability, credit and asset growth, and external ratings in a group of countries where the two types of banks have significant market share. They suggest that IBs have been affected differently than CBs. Factors related to IBs business model helped limit the adverse impact on profitability in 2008, while weaknesses in risk management practices in some IBs led to a larger decline in profitability in 2009 compared to CBs. IBs credit and asset growth performed better than did that of CBs in 2008-09, contributing to 
financial and economic stability. External rating agencies-assessment of IBs risk was generally more favorable.

Ait-Sahalia, et al (2012) examines the impact of macroeconomic and financial sector policy announcements in the United States, the United Kingdom, the euro area, and Japan on interbank credit and liquidity risk premia during the recent crisis. Overall, policy interventions were associated with a reduction in interbank risk premia, most significantly for recapitalization programs. By contrast, decisions to bail out individual banks in an ad hoc manner or let them fail were accompanied by a significant rise in interbank risk premia. Most policy announcements had international spillovers. These results are broadly robust to using alternative measures of financial distress and varying the size of the event window.

While many of previous studies address the origins of global financial crisis, the current study examines its effects. Moreover, it focuses on financial effects, while literature concerns with macroeconomic indicators. Besides, it examines developed and emerging markets and covers several sectors. So, cross-country and cross-industry multi-period analysis may add to its significance.

\section{Data Description and Hypotheses Test}

Required data include sector indices of banking, insurance and real estate sectors, for the all period, the pre-crisis and during-crisis periods. As mentioned below table (1), data of market indices are: "EGX 30", "Kuwait Stock Exchange Market Index", "FTSE100" and "The Dow Jones U.S. Index". The following table shows variables used for testing hypotheses:

Table 3: Variables representing sector indices

\begin{tabular}{c|cc}
\hline Variable & Calculation & Sign \\
\hline EGBAN & $\Delta$ in Egyptian Banking Sector Index & EGBAN \\
EGINS & $\Delta$ in Egyptian Insurance Sector Index & EGINS \\
EGREA & $\Delta$ in Egyptian Real estate Sector Index & EGREA \\
KUBAN & $\Delta$ in Kuwaiti Banking Sector Index & KUBAN \\
KUINS & $\Delta$ in Kuwaiti Insurance Sector Index & KUINS \\
KUREA & $\Delta$ in Kuwaiti Real estate Sector Index & KUREA \\
UKBAN & $\Delta$ in British Banking Sector Index & UKBAN \\
UKINS & $\Delta$ in British Insurance Sector Index & UKINS \\
UKREA & $\Delta$ in British Real estate Sector Index & UKREA \\
USBAN & $\Delta$ in American Banking Sector Index & USBAN \\
USINS & $\Delta$ in American Insurance Sector Index & USINS \\
USREA & $\Delta$ in American Real estate Sector Index & USREA \\
\hline
\end{tabular}

This paper aims at testing the following two hypotheses:

- There are no significant differences between average changes in sector indices of stock markets, according to their industry.

- There are no significant differences between average changes in sector indices of stock markets, according to their country.

Regarding the first hypothesis, the null hypothesis $\mathrm{H}_{0}$ could be shown as: 


$\begin{aligned} & \mu_{\text {EG-BAN }}=\mu_{\text {EG-INS }}=\mu_{\text {EG-REA }} \\ & \mu_{\text {KU-BAN }}=\mu_{\text {KU-INS }}=\mu_{\text {KU-REA }} \\ & \mu_{\text {UK-BAN }}=\mu_{\text {UK-INS }}=\mu_{\text {UK-REA }} \\ & \mu_{\text {US-BAN }}=\mu_{\text {US-INS }}=\mu_{\text {US-REA }}\end{aligned}$

The alternative hypothesis $\mathrm{H}_{\mathrm{a}}$ states that, for each country " $\mathrm{CO}$ ":

$$
\mu_{\text {CO-BAN }} \neq \mu_{\text {CO-NS }} \neq \mu_{\text {CO.REA }}
$$

Regarding the second hypothesis, the null hypothesis $\mathrm{H}_{0}$ could be shown as:

$\begin{aligned} & \mu_{\text {EG-BAN }}=\mu_{\text {KU-BAN }}=\mu_{\text {UK-BAN }}=\mu_{\text {US-BAN }} \\ & \mu_{\text {EG-INS }}=\mu_{\text {KU-INS }}=\mu_{\text {UK-INS }}=\mu_{\text {US-INS }} \\ & \mu_{\text {EG-REA }}=\mu_{\text {KU-REA }}=\mu_{\text {UK-REA }}=\mu_{\text {US-REA }}\end{aligned}$

The alternative hypothesis $\mathrm{H}_{\mathrm{a}}$ states that, for each industry "IN":

$$
\mu_{\mathrm{EG- \textrm {N }}} \neq \mu_{\mathrm{KU- \textrm {N }}} \neq \mu_{\mathrm{UK} \text {-IN }} \neq \mu_{\mathrm{US}-\mathrm{NN}}
$$

\section{Results of Empirical Study}

Required data include average monthly changes in sector indices of banking, insurance and real estate sectors, for the all period, the pre-crisis and during-crisis periods. Data cover the period from January 2007 to December 20011. The beginning of during-crisis period is determined by the continuous decline in sector indices that took place in June 2008. The following table illustrates descriptive statistics of these data for the Egyptian stock market: 
Table 4: Descriptive statistics of Egyptian sector indices

\begin{tabular}{c|c|cccc}
\hline Period & Variable & Minimum & Maximum & Mean & Std. Deviation \\
\hline 2007 & EGBAN & -.3334 & .2651 & .007286 & .1060490 \\
to & EGINS & -.3053 & .2606 & -.007380 & .1192369 \\
2011 & EGREA & -.3558 & .3933 & -.001946 & .1331976 \\
\hline \multirow{3}{*}{ Pre-crisis } & EGBAN & -.0805 & .1273 & .029081 & .0506173 \\
& EGINS & -.1759 & .1872 & .033606 & .0801125 \\
& EGREA & -.0675 & .2221 & .062562 & .0837281 \\
\hline \multirow{3}{*}{ During-crisis } & EGBAN & -.3334 & .2651 & -.001433 & .1208389 \\
& EGINS & -.3053 & .2606 & -.023775 & .1289065 \\
& EGREA & -.3558 & .3933 & -.027750 & .1411869 \\
\hline
\end{tabular}

The previous table shows that sector indices of Egyptian stock market have been increased in the pre-crisis period (by means ranged from $2.91 \%$ to $6.26 \%$ ), while they have been decreases in the during-crisis period (by means ranged from $-0.14 \%$ to $2.78 \%$ ). For the all period, sector indices of insurance and real estate have been decreased, while sector index of banking has been increased.

The following table illustrates descriptive statistics of these data for the Kuwaiti stock market:

Table 5: Descriptive statistics of Kuwaiti sector indices

\begin{tabular}{c|c|cccc}
\hline Period & Variable & Minimum & Maximum & Mean & Std. Deviation \\
\hline 2007 & KUBAN & -.1453 & .1394 & .003966 & .0587955 \\
to & KUINS & -.2365 & .1542 & -.004286 & .0728359 \\
2011 & KUREA & -.2457 & .1690 & -.012585 & .0697672 \\
\hline \multirow{3}{*}{ Pre-crisis } & KUBAN & -.0541 & .0858 & .023144 & .0404926 \\
& KUINS & -.0514 & .1154 & .028422 & .0446387 \\
& KUREA & -.0719 & .0970 & .028006 & .0480934 \\
\hline \multirow{3}{*}{ During-crisis } & KUBAN & -.0541 & .0858 & -.004454 & .0404926 \\
& KUINS & -.0514 & .1154 & -.018646 & .0446387 \\
& KUREA & -.0719 & .0970 & -.030405 & .0480934 \\
\hline
\end{tabular}

The previous table shows that sector indices of Kuwaiti stock market have been increased in the pre-crisis period (by means ranged from $2.31 \%$ to $2.84 \%$ ), while they have been decreases in the during-crisis period (by means ranged from $-0.45 \%$ to $-3.04 \%$ ). For the all period, sector indices of insurance and real estate have been increased, while sector index of banking has been increased.

The following table illustrates descriptive statistics of these data for the British stock market: 
Table 6: Descriptive statistics of British sector indices

\begin{tabular}{c|c|cccc}
\hline Period & Variable & Minimum & Maximum & Mean & Std. Deviation \\
\hline 2007 & UKBAN & -.2957 & .2937 & -.015185 & .1049900 \\
to & UKINS & -.2473 & .1936 & -.004561 & .0888585 \\
2011 & UKREA & -.3010 & .1709 & -.014763 & .0791851 \\
\hline \multirow{3}{*}{ Pre-crisis } & UKBAN & -.0739 & .0627 & -.020694 & .0333374 \\
& UKINS & -.0885 & .0884 & -.011331 & .0488567 \\
& UKREA & -.1130 & .0723 & -.031237 & .0622129 \\
\hline \multirow{3}{*}{ During-crisis } & UKBAN & -.2957 & .2937 & -.013135 & .1216936 \\
& UKINS & -.2473 & .1936 & -.002042 & .1001365 \\
& UKREA & -.3010 & .1709 & -.008633 & $\mathbf{. 0 8 4 4 6 7 6}$ \\
\hline
\end{tabular}

The previous table shows that sector indices of British stock market have been decreased in the pre-crisis period (by means ranged from $-1.13 \%$ to $-3.12 \%$ ), and they have been decreases in the during-crisis period (by means ranged from $-0.86 \%$ to $-1.31 \%$ ). For the all period, sector indices have been decreased (by means ranged from $-0.46 \%$ to $-1.52 \%$ ). The following table illustrates descriptive statistics of these data for the American stock market:

Table 7: Descriptive statistics of American sector indices

\begin{tabular}{c|c|cccc}
\hline Period & Variable & Minimum & Maximum & Mean & Std. Deviation \\
\hline 2007 & USBAN & -.2053 & .2032 & -.010161 & .0789500 \\
to & USINS & -.1464 & .2042 & .002354 & .0611213 \\
2011 & USREA & -.3126 & .2518 & -.003020 & .0969498 \\
\hline \multirow{3}{*}{ Pre-crisis } & USBAN & -.1086 & .0716 & -.015719 & .0509403 \\
& USINS & -.0857 & .0455 & -.001731 & .0389655 \\
& USREA & -.0845 & .0782 & -.007775 & .0508730 \\
\hline \multirow{3}{*}{ During-crisis } & USBAN & -.2053 & .2032 & -.008093 & .0875484 \\
& USINS & -.1464 & .2042 & .003874 & .0678823 \\
& USREA & -.3126 & .2518 & -.001251 & $\mathbf{. 1 0 9 7 4 4 3}$ \\
\hline
\end{tabular}

The previous table shows that sector indices of American stock market have been decreased in the pre-crisis period (by means ranged from $-0.78 \%$ to $-1.57 \%$ ). For the during-crisis period and for the all period, sector indices of banking and real estate have been decreased, while sector index of insurance has been increased.

Regarding the first hypothesis, Kruskal- Wallis test is used to check the significance of differences between average changes in sector indices of stock markets, according to their industry, for all the period, for the pre-crisis period and for the during-crisis period. The following table illustrates the results of this test as follows: 
Table 8: Testing the first hypothesis: Industry Analysis

\begin{tabular}{|c|c|c|c|c|c|}
\hline Period & Sector & Egypt & Kuwait & $U \boldsymbol{U}$ & $U S A$ \\
\hline \multirow{3}{*}{ For all period } & Banking & $\begin{array}{l}\mathbf{0 . 0 0 7 3} \\
(24.291) * * *\end{array}$ & $\begin{array}{l}\mathbf{0 . 0 0 4 0} \\
(28.001) * * *\end{array}$ & $\begin{array}{l}\mathbf{- 0 . 0 1 5 2} \\
(26.793) * * *\end{array}$ & $\begin{array}{l}\mathbf{- 0 . 0 1 0 2} \\
(28.681) * * *\end{array}$ \\
\hline & Insurance & $\begin{array}{l}\mathbf{- 0 . 0 0 7 4} \\
(31.940) * * *\end{array}$ & $\begin{array}{l}\mathbf{- 0 . 0 0 4 3} \\
(38.081) * * *\end{array}$ & $\begin{array}{l}\mathbf{- 0 . 0 0 4 6} \\
(29.038) * * *\end{array}$ & $\begin{array}{l}\mathbf{0 . 0 0 2 4} \\
(24.301) * * *\end{array}$ \\
\hline & Real Estate & $\begin{array}{l}\mathbf{- 0 . 0 0 1 9} \\
(29.573) * * *\end{array}$ & $\begin{array}{l}\mathbf{- 0 . 0 1 2 6} \\
(34.786) * * *\end{array}$ & $\begin{array}{l}\mathbf{- 0 . 0 1 4 8} \\
(8.871)^{* * *}\end{array}$ & $\begin{array}{l}\mathbf{- 0 . 0 0 3 0} \\
(31.008) * * *\end{array}$ \\
\hline \multirow{3}{*}{ Before Crisis } & Banking & $\begin{array}{l}\mathbf{0 . 0 2 9 1} \\
(0.059)\end{array}$ & $\begin{array}{l}\mathbf{0 . 0 2 3 1} \\
(2.558)\end{array}$ & $\begin{array}{l}\mathbf{- 0 . 0 2 0 7} \\
(3.050)^{*}\end{array}$ & $\begin{array}{l}\mathbf{- 0 . 0 1 5 7} \\
(6.893) * * *\end{array}$ \\
\hline & Insurance & $\begin{array}{l}\mathbf{0 . 0 3 3 6} \\
(1.779)\end{array}$ & $\begin{array}{l}\mathbf{0 . 0 2 8 4} \\
(5.898) * *\end{array}$ & $\begin{array}{l}\mathbf{- 0 . 0 1 1 3} \\
(3.118)^{* *}\end{array}$ & $\begin{array}{l}\mathbf{- 0 . 0 0 1 7} \\
(3.188) * *\end{array}$ \\
\hline & Real Estate & $\begin{array}{l}\mathbf{0 . 0 6 2 6} \\
(2.882)^{*}\end{array}$ & $\begin{array}{l}\mathbf{0 . 0 2 8 0} \\
(6.488)^{* *}\end{array}$ & $\begin{array}{l}\mathbf{- 0 . 0 3 1 2} \\
(0.810)\end{array}$ & $\begin{array}{l}\mathbf{- 0 . 0 0 7 8} \\
(7.456) * * *\end{array}$ \\
\hline \multirow{3}{*}{ During Crisis } & Banking & $\begin{array}{l}\mathbf{- 0 . 0 0 1 4} \\
(23.418) * * *\end{array}$ & $\begin{array}{l}\mathbf{- 0 . 0 0 4 5} \\
(20.924) * * *\end{array}$ & $\begin{array}{l}\mathbf{- 0 . 0 1 3 1} \\
(21.311)^{* * * *}\end{array}$ & $\begin{array}{l}\mathbf{- 0 . 0 0 8 1} \\
(20.691) * * *\end{array}$ \\
\hline & Insurance & $\begin{array}{l}\mathbf{- 0 . 0 2 3 8} \\
(26.123) * * *\end{array}$ & $\begin{array}{l}\mathbf{- 0 . 0 1 8 6} \\
(23.212)^{*} * *\end{array}$ & $\begin{array}{l}\mathbf{- 0 . 0 0 2 0} \\
(20.643) * * *\end{array}$ & $\begin{array}{l}\mathbf{0 . 0 0 3 9} \\
(20.693) * * *\end{array}$ \\
\hline & Real Estate & $\begin{array}{l}\mathbf{- 0 . 0 2 7 8} \\
(23.949) * * *\end{array}$ & $\begin{array}{l}\mathbf{- 0 . 0 3 0 4} \\
(20.188) * * *\end{array}$ & $\begin{array}{l}\mathbf{- 0 . 0 0 8 6} \\
(9.947) * * *\end{array}$ & $\begin{array}{l}\mathbf{- 0 . 0 0 1 3} \\
(22.976) * * *\end{array}$ \\
\hline
\end{tabular}

Each cell contains the average change in relevant market index, with the significance level according to chi-square value of Kruskal-Wallis test, where * denotes p-value of $10 \%, * *$ denotes $5 \%$ and $* * *$ denotes $1 \%$.

Regarding the first hypothesis, Kruskal- Wallis test shows, at p-value of 0.01, that there's a significant differences between average changes in sector indices of stock markets, according to their industries, as follows:

- For all the period: The most negatively affected sector is "insurance" for the Egyptian market, and "real estate" for the Kuwaiti market, while "banking" is the most negatively affected sector for the British and American markets.

- For the pre-crisis period: The most negatively affected sector is "banking" for American market, while the Egyptian, Kuwaiti and British markets have not been affected.

- For the during-crisis period: The most negatively affected sector is "real estate" for the Egyptian and Kuwaiti markets, while "banking" is still the most negatively affected sector for the British and American markets.

Based on the previous analysis, the null hypothesis is rejected. This means that the alternative one could be accepted showing existence of "industry effect".

Regarding the second hypothesis, Kruskal- Wallis test is used to check the significance of differences between average changes in sector indices of stock markets, according to their countries, for all the period, for the pre-crisis period and for the during-crisis period. The following table illustrates the results of this test as follows: 
Table 9: Testing the second hypothesis: Country Analysis

\begin{tabular}{|c|c|c|c|c|}
\hline Period & Country & Banking & Insurance & Real Estate \\
\hline \multirow{4}{*}{ For all period } & Egypt & $\begin{array}{c}\mathbf{0 . 0 0 7 3} \\
(6.673) * * *\end{array}$ & $\begin{array}{c}\mathbf{- 0 . 0 0 7 4} \\
(6.785)^{* * *}\end{array}$ & $\begin{array}{c}\mathbf{- 0 . 0 0 1 9} \\
(6.704)^{* * *} \\
\end{array}$ \\
\hline & Kuwait & $\begin{array}{c}\mathbf{0 . 0 0 4 0} \\
(6.696) * * *\end{array}$ & $\begin{array}{c}\mathbf{- 0 . 0 0 4 3} \\
(6.935) * * * \\
\end{array}$ & $\begin{array}{c}\mathbf{- 0 . 0 1 2 6} \\
(5.832)^{* *}\end{array}$ \\
\hline & UK & $\begin{array}{c}\mathbf{- 0 . 0 1 5 2} \\
(9.950)^{* * *}\end{array}$ & $\begin{array}{c}\mathbf{- 0 . 0 0 4 6} \\
(9.744) * * *\end{array}$ & $\begin{array}{c}\mathbf{- 0 . 0 1 4 8} \\
(0.200) \\
\end{array}$ \\
\hline & USA & $\begin{array}{c}\mathbf{- 0 . 0 1 0 2} \\
(4.774)^{* *} \\
\end{array}$ & $\begin{array}{c}\mathbf{0 . 0 0 2 4} \\
(5.558)^{* *} \\
\end{array}$ & $\begin{array}{c}\mathbf{- 0 . 0 0 3 0} \\
(6.484) * * \\
\end{array}$ \\
\hline \multirow{4}{*}{ Before Crisis } & Egypt & $\begin{array}{l}\mathbf{0 . 0 2 9 1} \\
(0.059) \\
\end{array}$ & $\begin{array}{r}\mathbf{0 . 0 3 3 6} \\
(1.779) \\
\end{array}$ & $\begin{array}{c}\mathbf{0 . 0 6 2 6} \\
(2.882)^{*} \\
\end{array}$ \\
\hline & Kuwait & $\begin{array}{l}\mathbf{0 . 0 2 3 1} \\
(0.059) \\
\end{array}$ & $\begin{array}{l}\mathbf{0 . 0 2 8 4} \\
(0.529) \\
\end{array}$ & $\begin{array}{c}\mathbf{0 . 0 2 8 0} \\
(0.059) \\
\end{array}$ \\
\hline & UK & $\begin{array}{r}\mathbf{- 0 . 0 2 0 7} \\
(0.015) \\
\end{array}$ & $\begin{array}{c}\mathbf{- 0 . 0 1 1 3} \\
(0.015) \\
\end{array}$ & $\begin{array}{c}\mathbf{- 0 . 0 3 1 2} \\
(4.765)^{* *}\end{array}$ \\
\hline & USA & $\begin{array}{l}\mathbf{- 0 . 0 1 5 7} \\
(2.485)\end{array}$ & $\begin{array}{l}\mathbf{- 0 . 0 0 1 7} \\
(0.368)\end{array}$ & $\begin{array}{c}\mathbf{- 0 . 0 0 7 8} \\
3.309)^{*}\end{array}$ \\
\hline \multirow{4}{*}{ During Crisis } & Egypt & $\begin{array}{c}\mathbf{- 0 . 0 0 1 4} \\
(23.418)^{* * * *}\end{array}$ & $\begin{array}{c}\mathbf{- 0 . 0 2 3 8} \\
(26.123)^{* * *} \\
\end{array}$ & $\begin{array}{c}\mathbf{- 0 . 0 2 7 8} \\
(23.949) * * * \\
\end{array}$ \\
\hline & Kuwait & $\begin{array}{c}\mathbf{- 0 . 0 0 4 5} \\
(6.392) * * \\
\end{array}$ & $\begin{array}{c}\mathbf{- 0 . 0 1 8 6} \\
(2.841)^{*} \\
\end{array}$ & $\begin{array}{c}\mathbf{- 0 . 0 3 0 4} \\
(7.092)^{* * *} \\
\end{array}$ \\
\hline & UK & $\begin{array}{c}\mathbf{- 0 . 0 1 3 1} \\
(11.548)^{* * *}\end{array}$ & $\begin{array}{c}\mathbf{- 0 . 0 0 2 0} \\
(12.491)^{* * *}\end{array}$ & $\begin{array}{c}\mathbf{- 0 . 0 0 8 6} \\
(7.797)^{* * *}\end{array}$ \\
\hline & USA & $\begin{array}{c}\mathbf{- 0 . 0 0 8 1} \\
(9.945) * * *\end{array}$ & $\begin{array}{c}\mathbf{0 . 0 0 3 9} \\
(8.863) * * *\end{array}$ & $\begin{array}{c}\mathbf{- 0 . 0 0 1 3} \\
(15.540)^{* * *}\end{array}$ \\
\hline
\end{tabular}

Each cell contains the average change in relevant market index, with the significance level according to chi-square value of Kruskal-Wallis test, where * denotes p-value of $10 \%$, ** denotes $5 \%$ and $* * *$ denotes $1 \%$.

Regarding the second hypothesis, Kruskal- Wallis test shows, at p-value of 0.01 , that there's a significant differences between average changes in sector indices of stock markets, according to their countries, as follows:

- For all the period: Regarding banking sector, the Egyptian and Kuwaiti markets are affected by industry, showing positive average changes in market indices, while the "British" market is the most negatively affected one. For each of insurance and real estate sectors, the "Egyptian" market is the most negatively affected one.

- For the pre-crisis period: Tests doesn't show any significant difference between indices due to their countries.

- For during-crisis period: The "British" market is the most negatively affected one in banking sector, while the "Egyptian" and the "Kuwaiti" markets are the most negatively affected ones in insurance and real estate sectors respectively.

Based on the previous analysis, the null hypothesis is rejected. This means that the alternative one could be accepted showing existence of "country effect". This may be consistent with the notion that cyclical industries seem to have been hit hard by the global financial crisis. Moreover, results support that the "real estate" and "insurance" sectors are more negatively affected in emerging markets than in developed ones, while "banking" sector is more negatively affected in developed markets than in emerging ones. 


\section{Summary and Concluded Remarks}

This paper aims at analyzing the "industry effect" on stock market reaction to global financial crisis. This has been conducted using a sample of 4 stock markets, and covering the period from 2007 to 2011.

Kruskal-Wallis tests indicated that we could accept hypotheses regarding the effects of "industry effect" on stock market reaction to global financial crisis in Egyptian, Kuwaiti, American and British stock markets for all the research period and for the during-crisis period. Also, they referred to the need to reject the hypotheses regarding these effects in all stock markets, for the pre-crisis period.

Tests indicated that we could accept hypotheses regarding the effects of "country effect" on stock market reaction to global financial crisis in banking, insurance and real estate sectors. Results of "country effect" tests are consistent with those of "industry effect" in periods and sectors. Tests of the two hypotheses could be considered as robustness checks for each other.

For the British and American markets, "banking" is the most negatively affected sector, while for the Kuwaiti market; it was "real estate". For the Egyptian market, each of "real estate" and "insurance" sector took place as the most negatively affected sector, where results differed according to the type of analysis.

Results reveal that sectors have different sensitivities to the current financial crisis. These may be explained, as follows:

- Banking is the most negatively affected sector in developed markets and it doesn't appear for any of emerging markets. This may be consistent with illustrating origin of financial crisis by "banking panics".

- Real Estate is the most negatively affected sector in emerging markets and it doesn't appear for any of developed markets. This indicates that decisions of mortgage expansion were not sound enough. Also, importing construction materials, foreign exchange risk and governmental corruption may affect cost of construction, and consequently affect sector index of this sector.

- Insurance appears as the most negatively affected sector in Egyptian market according to some tests. High weights of mortgage investments of insurance companies may shed lights on this.

It's important to mention that selected countries and sectors were restricted by data availability and industries definition. If future research investigates other sectors along many other markets, this may help assess the effects global financial crisis. Also, other techniques as event studies are encouraged to be conducted and other periods could be covered.

\section{References}

[1] F. Allen, A. Babus \& E. Carletti, Financial Crises: Theory and Evidence, Annual Review of Financial Economics 1 (2009) 97-116. Retrieved from: http://ssrn.com/abstract $=1422715$.

[2] D. Nanto, The Global Financial Crisis: Analysis and Policy Implications. Congressional Research Service, (2009), Retrieved from: www.crs.gov

[3] L. Orlweski, Stages of the 2007/2008 Global Financial Crisis: Is There a Wandering Asset-Price Bubble?, (2008), Retrieved from: http://ssrn.com/abstract $=1726700$. 
[4] R. Ball, The Global Financial Crisis and the Efficient Market Hypothesis: What Have We Learned?, Journal of Applied Corporate Finance 21 (4), (2009), 8-16.

[5] L. Becchettiy, C. Ceniccolaz \& R. Cicirettix, Stock Market Reaction to the Global Financial Crisis: the Role of Corporate Governance and Product Quality Ratings in the Lehman Brothers' Event, (2010), Retrieved from: http://ssrn.com/abstract $=1648778$.

[6] Diamond, D. \& Rajan, R. (2009) "Fear of Fire Sales and the Credit Freeze," A working paper, University of Chicago.

[7] V. Acharya, D. Gale \& T. Yorulmazer, Rollover Risk and Market Freezes, A working paper, New York University, (2009).

[8] F. Heider, M. Hoerova, \& C. Holthausen, Liquidity Hoarding and Interbank Market Spreads: The Role of Counterparty Risk, Mimeo European Central Bank, (2009), Frankfurt.

[9] P. Bolton, T. Santos\& J. Scheinkman, Inside and Outside Liquidity, A working paper, Columbia University, (2008).

[10] F. Allen, \& D. Gale, Financial Contagion, Journal of Political Economy 108, (2000), $1-33$.

[11] Y. Leitner, Financial Networks: Contagion, Commitment, and Private Sector Bailouts, Journal of Finance 60, (2005), 2925-2953.

[12] L. Eisenberg, \& T. Noe, Systemic Risk in Financial Systems, Management Science 47(2), (2001), 236-249.

[13] G. Minguez-Afonso \& H. Shin, Systemic Risk and Liquidity in Payment Systems, A working paper, London School of Economics, (2007).

[14] P. Gai \& S. Kapadia, Contagion in Financial Networks, A working paper, Bank of England, (2007).

[15] R. Lagunoff \& S. Schreft, A Model of Financial Fragility, Journal of Economic Theory 99, (2001), 220-264.

[16] T. Adrian, \& H. Shin, Liquidity and Leverage, Journal of Financial Intermediation 19 (3), (2010), 418-437.

[17] M. Boyson, C. Stahel \& R. Stulz, Hedge Fund Contagion and Liquidity, A working paper, Ohio State University, (2008).

[18] C. Parlour, \& A. Winton, Laying off Credit Risk: Loan Sales versus Credit Default Swaps, A working paper, University of Berkeley, (2008).

[19] H. Shin, Securitization and Financial Stability, Economic Journal 119, (2009), 309-332.

[20] F. Allen, \& E. Carletti, Credit Risk Transfer and Contagion, Journal of Monetary Economics 53, (2006), 89-111

[21] B. Bernanke, Liquidity Provision by the Federal Reserve, Board of Governors of the Federal Reserve System, (2008), Retrieved from: www.federalreserve.gov/newsevents/speech/bernanke20080513.htm.

[22] R. Herring \& S. Wachter, Bubbles in Real Estate Markets, Asset Price Bubbles: The Implications for Monetary, Regulatory, and International Policies, edited by William C. Hunter, George G. Kaufman, and Michael Pomerleano, Cambridge: MIT Press, (2003).

[23] C., Mayer, K. Pence \& S. Sherlund, The Rise in Mortgage Defaults, Journal of Economic Perspectives 41, (2009).

[24] P. Berkmen, G. Gelos, R. Rennhack, \& J. Walsh, The Global Financial Crisis: Explaining Cross-Country Differences in the Output Impact, (2009) Retrieved from: 
http://ssrn.com/abstract $=1531513$.

[25] M. Hasan, \& J. Dridi, The Effects of the Global Crisis on Islamic and Conventional Banks: A Comparative Study, International Monetary Fund Working Paper, 10/201, (2010), Retrieved from: http://ssrn.com/abstract=750689.

[26] Y. Aït-Sahalia, J. Andritzky, A. Jobst, S. Nowak, \& N. Tamirisa , Market Response to Policy Initiatives during the Global Financial Crisis, Journal of International Economics 87 (2012) 162-177. 